\title{
Mathematical Education in the Opinion of the Students of Integrated Early-School Education - A Study Report
}

\author{
Ewelina Kawiak
}

\author{
Master's degree, Assistant, researcher and lecturer \\ University of Silesia in Katowice, Faculty of Pedagogy and Psychology, \\ Institute of Education, Department of Early Education and Pedagogy Media
}

\section{Doi:10.5901/jesr.2013.v3n7p69}

\begin{abstract}
Mathematics is considered one of the most important school subjects. Despite that fact, assimilation of mathematical knowledge causes many students numerous problems. Studying mathematics does not only consist in acquiring skills that are essential in solving specific tasks. It is, above all, a process thanks to which the basic competences needed in everyday life are developed. The benefits gained from studying mathematics go far beyond classroom environment and cover fields that are unrelated to the realm of pure mathematics. The significant role of mathematical education is recognized by both teachers and parents. However, what do the students themselves think about that issue? This article attempts to find an answer to that question. It presents the results of the study conducted among the elementary school second-and third-grade students. The analysis of the obtained results enables us to get to know students' point of view on mathematical education, methods of teaching this subject as well as task-solving techniques. Additionally, the motivation to study maths that students present is another issue raised in the article. The results obtained in this study may help to facilitate the didactic process by means of making mathematics classes more engaging for the students. Teaching this subject in accordance with students' preferences will most likely increase the efficiency of teaching and will reduce their reluctance to explore this subject in depth.
\end{abstract}

Keywords: mathematical education, motivation to study maths, students' opinions about mathematics

\section{Introduction}

It is not possible to sum up all the areas of competence, which develop during the process of acquisition of mathematical knowledge. To a large extent, it is thanks to them that we are able to function properly in the contemporary world filled with mathematical content. There are two basic objectives that are commonly observed in learning mathematics: acquiring certain information, notions, theorems and algorithms by the learners as well as developing the skills of logical and abstract thinking, forming the abilities of critical thought formulation, reasoning and deduction (Siwek, 2005). The significant influence of "the queen of the sciences" on the comprehensive development of a human was noticed by the scholars ages ago and still constitutes an essential element of school curricula. The current curricular basis for general education in Poland defines mathematical thinking as one of the main skills which each student should acquire during general education in the elementary school (The curricular basis for general education in elementary schools, 2008).

Teaching mathematics should be learner-friendly but also effective from the point of view of a teacher. M. Skura (Swoboda, Gunčaga, 2009) claims that the child-friendly mathematical education is the one which: makes the children like mathematics lessons and encourages them to willingly participate in them; brings about the required effects such as: the child gains new skills and knowledge; respects developmental regularities of child's reasoning and the current level of child's development; provides the child with appropriately selected experiences.

Whilst deliberating on the process of teaching and learning mathematics one must bear in mind the principle that teaching is effective only when the methods applied by a teacher stimulate learners' activity, make their minds work and positively influence their reasoning, experiencing, remembering and discovering new notions (Siwek, 2005). In the current approach to teaching, the considerable emphasis is put on students' independence in the process of knowledge acquisition. While accepting children's natural passion for learning, the educators agree that children find it particularly enjoyable to be capable of making their own discoveries. It is the job of a teacher to create such didactic situations that learning mathematics might become a fascinating adventure for the students (Semadeni, 1981). This objective can be achieved by applying teaching through problems, which, while referring to divergent thinking, makes student's work more 
vivid and stimulating to further quest for knowledge, which entails creative thinking (Zborowski, 1986). Teaching mathematics in school environment, has been largely reduced to students' mechanical revising the previously covered patterns of behaviour, whose meaning remains often incomprehensible and remote. Limiting students' activity merely to memorizing mathematical rules often blocks out their readiness for and ability of mathematical thinking (Klus-Stańska, Nowicka, 2005). The consequence of such a condition is the phenomenon of so-called mathematical mindlessness, understood as the lack of ability to reach out beyond the mechanical computational techniques and inability to form one's own strategies of conduct in new situations (Klus-Stańska, Kalinowska, 2004).

There is a certain relationship between students' approach to learning mathematics and the duration of school education. While the youngest learners declare that mathematics is their favourite school subject, as the time goes by, their enthusiasm fades and turns into discouragement and increasing fear of maths (Klus-Stańska, Kalinowska, 2004). The difficulties which appear in the process of learning cause that students start to avoid contacts with mathematics, which in turn makes them fall behind even further. Many students suffer numerous failures whilst studying mathematics, the result of which is the slowdown in their intellectual development.

The research shows that the main cause of failure in the process of learning mathematics is starting the school education by the children who are not mature enough to learn this subject in the classroom - lesson context (GruszczykKolczyńska, 1997). School teaching of that subject requires the learners to be able to think in terms of precise operations and operational logic (Gruszczyk-Kolczyńska, Zielińska, 1997).

When a student does not yet function on a suitable level of reasoning, teaching him mathematics is virtually impossible. Experiencing failure while learning, and sometimes even the very process of learning makes students suffer from stres, increasing frustration and lack of confidence when it comes to one's own abilities. Thus, the factor which largely determines_a proper learning process of mathematics is the appropriate level of emotional resistance to the difficult situations that may occur. It is particularly important in the context of mathematics where a learner should demonstrate such a level of emotional resistance that would enable him to solve a task despite increasing tensions. (Gruszczyk-Kolczyńska, 1997). Learning mathematics involves problem solving. According to Zofia Cydzik (1990, p. 139) the ability to solve text exercises is integrally connected with the entirety of mathematical knowledge that students present. One of the main benefits coming from problem solving is the fact that these problems influence the development of intellectual conduct which is displayed in creative, critical and logical thinking (Gruszczyk-Kolczyńska, 1997). The students demonstrate significant difficulties in solving text exercises. To a large extent, they result from inappropriate teaching methods. The major obstacle that does not allow students to master the subject is the way in which mathematics is thought (Davis, Braun, 2006, p. 73). During school lessons, students solve the problems and do exercises but the methods of solving them are not taught (Nowik, 2009). Problem tasks play an especially significant role in mathematical education. Anna Kalinowska assumes that they are the assignments which a student cannot solve using merely the algorithmic knowledge that he has. It is necessary for him to be able to demonstrate the productive thinking skills, which leads to the enrichment of his subject knowledge. (Kalinowska, 2010, p. 26).

The motivation for studying is an essential issue since it largely conditions the school achievements. There are several activities which stimulate the positive motivation for studying: providing students with a fair reward system, rewarding learners' achievements as well as their curiosity, appreciating various skills, offering alternative motivations and suggesting tasks that involve the participants (Covington, Teel, 2004). The above mentioned actions may be effectively applied in the process of teaching mathematics. The school and home environment are the major sources of motivation for learning (Węglińska, 1999). Both of these environments should be equally involved in the process of learning mathematics by a child. M. Wegglińska points out that it is necessary for a teacher to cooperate with a child's family in order to create suitable incentives needed to motivate a child to learn (1999, quoting Gerstman, 1962). It is also crucial that the persons that play a significant role in a child's life, such as parents, teachers, carers would not project their own prejudice or aversion towards mathematics onto the children. The belief in the necessity of modifications in the teaching methods from the earliest years of child's presence at school led to a deeper consideration of the current state of affairs. In the light of the previously mentioned deliberations, is seems justified to scrutinize what students themselves think of mathematics. Being aware of students' opinions about math classes, the recognition of their motivation for studying the subject and the knowledge about the most suitable classwork methods is a vital issue for teachers who desire to obtain the best possible results in their own work and their students'. This article is a review of students' opinions on mathematics in the integrated early-school education. 


\section{Mathematical education in the opinion of the students of integrated early-school education - a study report}

The basis that was used to define students' opinions on mathematics in the integrated early-school education was the analysis of the data obtained in the diagnostic survey conducted among the second grade students of elementary school. The survey consisted of a questionnaire, interviews and a sentence completion test. The participants were 92 pupils from one of the Polish elementary schools, situated in Będzin, Silesia region. A variable taken into account while analyzing the results is gender.

Despite the common conviction concerning students' aversion towards mathematics, the empirical research results do not provide any evidence to support that view.

Out of all second grade students questioned, as many as $95 \%$ of them declare that they like mathematics lessons or even like them a lot (Table 1). The conducted survey only confirms the respondents' liking for this subject. A small percentage of students declare their dislike for mathematics or any form of activity related to mathematical tasks. Most of these pupils do not get satisfactory marks, which affects their negative attitude towards the subject itself.

Table 1. Response to the question: Do you like math classes? $(N=92)$

\begin{tabular}{|c|c|c|c|c|c|c|}
\hline \multirow{2}{*}{ Response } & \multicolumn{2}{|c|}{ Girls $(N=49)$} & \multicolumn{2}{c|}{ Boys $(N=43)$} & \multicolumn{2}{c|}{ Total $(N=92)$} \\
\cline { 2 - 7 } & Number & Percentage & Number & Percentage & Number & Percentage \\
\hline Like a lot & 24 & 49 & 29 & 67 & 53 & 58 \\
\hline Like & 22 & 45 & 12 & 28 & 34 & 37 \\
\hline Don't like & 3 & 6 & 2 & 5 & 5 & 5 \\
\hline
\end{tabular}

In the table, the responses of highest value are marked in bold.

Source: Author's own survey (Kawiak, unpubl. 2013)

The respondents demonstrated significant willingness to study mathematics and participate in mathematics classes (Table2).

Table 2. Response to the question: Do you want to learn mathematics? $(N=92)$

\begin{tabular}{|c|c|c|c|c|c|c|}
\hline \multirow{2}{*}{ Response } & \multicolumn{2}{|c|}{ Girls $(N=49)$} & \multicolumn{2}{c|}{ Boys $(N=43)$} & \multicolumn{2}{c|}{ Total $(N=92)$} \\
\cline { 2 - 7 } & Number & Percentage & Number & Percentage & Number & Percentage \\
\hline Yes & 38 & 78 & 31 & 72 & 69 & 75 \\
\hline Rather yes & 7 & 14 & 10 & 23 & 17 & 19 \\
\hline Rather no & 3 & 6 & 0 & 0 & 3 & 3 \\
\hline No & 1 & 2 & 2 & 5 & 3 & 3 \\
\hline
\end{tabular}

In the table, the responses of highest value are marked in bold.

Source: Author's own survey (Kawiak, unpubl. 2013)

From among all the respondents, $94 \%$ declare the they want to learn mathematics (responses 'yes' and 'rather yes'). This willingness is expressed by both sexes, however boys' responses slightly outnumber the girls'. Learners want to study mathematics because it is interesting, cool and useful in many respects ${ }^{1}$. The dislike expressed by few respondents results largely from their poor school results and gaps in the knowledge they present. These students describe mathematics as a difficult and uninteresting subject ${ }^{2}$.

A large percentage of students described mathematics as an area of knowledge that is useful for people (Table 3). According to them, its usefulness in everyday situations relates mostly to: financial calculations connected with purchase and sale, counting various objects, using the clock and calendar as well as forming three-dimensional block structures ${ }^{3}$.

\footnotetext{
${ }^{1}$ Most frequent responses when asked to complete the sentence: „Learning mathematics is........." . On the basis of the analysis of Incomplete Sentences Test. $\mathrm{N}=92$. Source: author's own research

2 Most frequent responses when asked to complete the sentence: „Learning mathematics is.......... . On the basis of the analysis of Incomplete Sentences Test. $N=92$. Source: author's own research

${ }^{3}$ Most frequent responses when asked to complete the sentence: „Mathematics is useful in........... . On the basis of the analysis of Incomplete Sentences Test. $\mathrm{N}=92$. Source: author's own research.
} 
Table 3. Response to the question: Is mathematics useful in life? $(N=92)$

\begin{tabular}{|c|c|c|c|c|c|c|}
\hline \multirow{2}{*}{ Response } & \multicolumn{2}{|c|}{ Girls $(N=49)$} & \multicolumn{2}{c|}{ Boys $(N=43)$} & \multicolumn{2}{c|}{ Total $(N=92)$} \\
\cline { 2 - 7 } & Number & Percentage & Number & Percentage & Number & Percentage \\
\hline It is useful in many respects & 45 & $\mathbf{9 2}$ & 40 & $\mathbf{9 3}$ & 85 & 92 \\
\hline It is useful but only at school & 3 & 6 & 3 & 7 & 6 & 7 \\
\hline It is not useful at all & 1 & 2 & 0 & 0 & 1 & 1 \\
\hline
\end{tabular}

In the table, the responses of highest value are marked in bold.

Source: author's own survey (Kawiak, unpubl. 2013)

Despite personal prejudice against the subject, students disliking mathematics, described it as useful. Out of all the pupils participating in the survey, only one person defined mathematics as a completely useless subject. Among all the responses there were also those saying that mathematics is useful only in the school context, only during classes (7\%). Such students do not see any practical real-life application of the skills acquired at school.

The survey also enabled the author to recognize the activities preferred by students demonstrated during mathematic classes at school (Table 4).

Table 4. Response to the question: What do you most like doing during math classes? $(N=92)$

\begin{tabular}{|l|c|c|c|c|c|c|}
\hline \multirow{2}{*}{ Response } & \multicolumn{2}{|c|}{ Girls $(N=49)$} & \multicolumn{2}{c|}{ Boys $(N=43)$} & \multicolumn{2}{c|}{ Total $(N=92)$} \\
\cline { 2 - 7 } & Number & Percentage & Number & Percentage & Number & Percentage \\
\hline Solving tasks & 15 & 31 & 3 & 7 & 18 & 20 \\
\hline Counting & 5 & 10 & 18 & $\mathbf{4 2}$ & 23 & 25 \\
\hline Drawing & 16 & 33 & 8 & 19 & 24 & 26 \\
\hline Using teaching aids (eg. abacus) & 0 & 0 & 1 & 2 & 1 & 1 \\
\hline $\begin{array}{l}\text { Coming up with my own strategies } \\
\text { to solve particular tasks }\end{array}$ & 1 & 2 & 1 & 2 & 2 & 2 \\
\hline Playing mathematical games & 12 & 24 & 12 & 28 & 24 & $\mathbf{2}$ \\
\hline
\end{tabular}

In the table, the responses of highest value are marked in bold.

Source: author's own survey (Kawiak, unpubl. 2013)

The research showed that the students' preferences in that respect are diversified by gender. The favourite activity mentioned by girls was solving mathematical tasks (31\%) whereas majority of boys prefers doing calculations (42\%). The activities preferred to a similar extent by representatives of both sexes are: making auxiliary drawings while solving tasks $(26 \%)$ and playing mathematical games (26\%). The need to refer to the graphic presentation of the contents while solving a task, may be explained by the fact that not all the second grade pupils are capable of operational thinking on the specific level (Gruszczyk-Kolczyńska, 1997). Making drawings helps students understand the abstract meaning of the mathematical tasks. A high percentage of students who readily play mathematical games, admits to their latent craving for adventure and competition. Introducing games while teaching mathematics is perfectly justified since 'games may be a good starting point for familiarizing students with new math notions, revising material and developing their skills; children are familiar with games and like them' (Czajkowska, 2005, p. 58).

Respondents attempted to define their motivation for studying mathematics. The research revealed three declared possibilities (Table 5).

Table 5. Response to the question: Who do you learn mathematics for? $(N=92)$

\begin{tabular}{|c|c|c|c|c|c|c|}
\hline \multirow{2}{*}{ Response } & \multicolumn{2}{|c|}{ Girls $(N=49)$} & \multicolumn{2}{c|}{ Boys $(N=43)$} & \multicolumn{2}{c|}{ Total $(N=92)$} \\
\cline { 2 - 7 } & Number & Percentage & Number & Percentage & Number & Percentage \\
\hline For myself & 27 & $\mathbf{5 5}$ & 26 & $\mathbf{6 1}$ & 53 & $\mathbf{5 8}$ \\
\hline For my parents & 8 & 16 & 4 & 9 & 12 & 13 \\
\hline For my teacher & 14 & 29 & 13 & 30 & 27 & 29 \\
\hline
\end{tabular}

In the table, the responses of highest value are marked in bold.

Source: author's own survey (Kawiak, unpubl. 2013) 
While learning mathematics, more than a half of respondents is driven by their willingness to acquire knowledge and skills necessary to be able to solve mathematical tasks. The inner drive that the learners declared indicates a large awareness of the significance of mathematical knowledge in everyday life. When asked 'Why do you learn mathematics?', the students most often replied: 'to know more, to be clever, to manage well in further education'4. Strong motivation for studying, so typical for early stages of education, is often connected with people who are significant characters in child's life. The will to satisfy the expectations of a class tutor is the most powerful motivation for one third of the respondents. Parents' expectations towards their children and their marks are also an essential incentive for kids to learn. $13 \%$ of the students studies in order to make their parents proud.

Students' engagement in knowledge acquisition is closely related to a didactic process. The more attractive and interesting the classes are, the more willingly the students participate in them. The data analysis provided us with the responses concerning the respondents' preferences when it comes to the scope of their favourite mathematical exercises (Table 6) and the most suitable classwork methods at mathematics lessons (Table 7). Not all types of mathematical tasks are equally attractive to students. The least popular with the respondents are those with one or more unknowns, frequently called exercises with a 'gap' (Table 6).

Table 6. Response to the question: What kind of mathematical problems do you most like solving ? $(N=92)$

\begin{tabular}{|c|c|c|c|c|c|c|}
\hline \multirow{2}{*}{ Response } & \multicolumn{2}{|c|}{ Girls $(N=49)$} & \multicolumn{2}{c|}{ Boys $(N=43)$} & \multicolumn{2}{c|}{ Total $(N=92)$} \\
\cline { 2 - 7 } & Number & Percentage & Number & Percentage & Number & Percentage \\
\hline Text exercises & 20 & 41 & 12 & 29 & 32 & 35 \\
\hline Arithemtical tasks & 20 & 41 & 27 & $\mathbf{6 3}$ & 47 & $\mathbf{5 1}$ \\
\hline Geometrical tasks & 6 & 12 & 2 & 4 & 8 & 9 \\
\hline Tasks with an uknown & 3 & 6 & 2 & 4 & 5 & 5 \\
\hline
\end{tabular}

In the table, the responses of highest value are marked in bold.

Source: author's own survey (Kawiak, unpubl. 2013)

The problems which are most willingly solved by the students are the arithmetical tasks which require calculations as well as the text tasks. It is interesting to observe that in comparison with the results obtained, the text tasks cause a great deal of difficulties for the lower grade elementary school pupils (Kalinowska, 2010).

Individual work is the favourite form of class work during mathematics lessons (Table 7). More than a half of all respondents declare that they find it most comfortable to work on their own. According to the research, individual task solving is also the dominant method of class work among the surveyed students.

Learners prefer to solve mathematical problems while working in pairs rather in small groups. Group work is considered the least attractive form of class work in the eyes of the respondents. Some of the students prefer to work out the solution to the problem jointly in the class while one pupil, indicated by the teacher or a volunteer, is solving the problem on the blackboard. However, this form of lesson work inherently involves a danger of poorer students copying an answer from the blackboard, being unable to work out the solution to the problem on their own.

Table 7. Response to the question: In what way do you most like to solve mathematical problems? $(N=92)$

\begin{tabular}{|c|c|c|c|c|c|c|}
\hline \multirow{2}{*}{ Response } & \multicolumn{2}{|c|}{ Girls $(N=49)$} & \multicolumn{2}{c|}{ Boys $(N=43)$} & \multicolumn{2}{c|}{ Total $(N=92)$} \\
\cline { 2 - 7 } & Number & Percentage & Number & Percentage & Number & Percentage \\
\hline On my own & 33 & 68 & 27 & 63 & 60 & 66 \\
\hline Pair work & 7 & 14 & 8 & 19 & 15 & 16 \\
\hline Group work & 0 & 0 & 2 & 4 & 2 & 2 \\
\hline Class work & 9 & 18 & 6 & 14 & 15 & 16 \\
\hline
\end{tabular}

In the table, the responses of highest value are marked in bold.

Source: author's own survey (Kawiak, unpubl. 2013)

Problem solving, similarly to studying mathematics, requires an appropriate level of emotional immunity. Faced with a

${ }^{4}$ On the basis of the analysis of the interviews conducted with the learners $\mathrm{N}=92$. Source: author's own (Kawiak, unpubl. 2013). 
particular problem they are not able to resolve, students produce certain defensive mechanisms which help them survive a stressful situation. Table 8 refers to the patterns of behavior indicated by the students in such situations. The respondents could tick more than one answer.

Table 8. Response to the question: What do you do when you cannot individually solve a particular problem in a math lesson?(N=92)

\begin{tabular}{|l|c|c|c|c|c|c|}
\hline \multirow{2}{*}{ Response } & \multicolumn{3}{|c|}{ Girls } & \multicolumn{2}{c|}{ Boys } & \multicolumn{3}{c|}{ Total } \\
\cline { 2 - 8 } & Number & Percentage & Number & Percentage & Number & Percentage \\
\hline Copy a ready answer from the blackboard & 37 & $\mathbf{5 8}$ & 30 & $\mathbf{5 2}$ & 67 & 55 \\
\hline Wait until someone else solves it & 10 & 15 & 8 & 14 & 18 & 14 \\
\hline Copy a friend's answer & 3 & 5 & 6 & 10 & 9 & 7 \\
\hline Guess the answer & 10 & 15 & 9 & 16 & 19 & 15 \\
\hline Say you are unwell to avoid having to solve it & 1 & 2 & 0 & 0 & 1 & 1 \\
\hline Occupy myself with other things & 0 & 0 & 2 & 3 & 2 & 2 \\
\hline Do not work on the problem at all & 0 & 0 & 3 & 5 & 3 & 3 \\
\hline Ask the teacher for assistance & 3 & 5 & 0 & 0 & 3 & 3 \\
\hline
\end{tabular}

In the table, the responses of highest value are marked in bold.

Source: author's own survey (Kawiak, unpubl. 2013)

The largest number of responses indicates that both girls and boys would resort to copying a ready answer from the board when they are unable to cope with the complexity of the mathematical problem. This pattern of behavior is facilitated in the situation when one student is doing the task on the blackboard, which is often the case in the surveyed groups. The least frequent situation is the one when students simulate somatic complaints in order to avoid solving the math task. Also, they rarely approach their teacher directly in case of such difficulties.

Having carried out a detailed analysis of the data obtained during the research, we got to know the opinions of the students of integrated early-school education concerning mathematics studies and the subject itself. Getting to know their opinions and preferences seems necessary and completely justified. These opinions constitute important indications for early-school education teachers with reference to how to organize the didactic process to make it interesting and inspiring for students.

\section{Conclusions}

The research results presented above indicate that the vast majority of students of early school integrated education have a positive opinion on mathematical education.

They want to study this subject and the learning process makes them happy. The students demonstrate high motivation for learning and they perceive mathematics as indispensable for humans to function properly in everyday life. This situation undoubtedly portends well for the educational future for the students. If their liking for mathematics does not change and their eagerness to learn does not lessen, they will not only be able to achieve very good scores in their studies but also, they will be able to further develop their intellectual potential.

The results obtained also constitute a challenge for the teachers. They should teach mathematics in such a way so as not to decrease their students' enthusiasm but to constantly stimulate their intellectual development and their motivation for learning. It is a pedagogue's job to spare no effort to make sure that in the eyes of the students, the didactic process is associated not with an unpleasant duty, but with intellectual challenge which they are eager to take and which brings about positive results. It is particularly important in case of studying mathematics, which determines our proper functioning in the contemporary world. Teachers of mathematics at every stage of school education should remember that, especially in the early school years.

\section{References}

Covington, M., V., Teel, K., M. (2004). Motywacja do nauki. Gdańsk: Gdańskie Wydawnictwo Psychologiczne.

Cydzik, Z. (1990). Nauczanie matematyki w klasie pierwszej i drugiej szkoły podstawowej. WSiP. 
Czajkowska, M. (2005). Wartości motywacyjne zadań matematycznych. Kielce: Wydawnictwo Akademii Świętokrzyskiej

Davis, R. D., Braun, E. M. (2006). Dar uczenia się. Poznań: Wydawnictwo Zysk i S-ka.

Gruszczyk-Kolczyńska, E., Zielińska, E. (1997). Dziecięca matematyka. Warszawa: WSiP.

Gruszczyk-Kolczyńska, E., (1997). Dzieci ze specyficznymi trudnościami w uczeniu się matematyki. Warszawa: WSiP.

Kalinowska, A. (2010). Matematyczne zadania problemowe w klasach początkowych - między wiedzą osobistą a jej formalizacją. Kraków: Oficyna Wydawnicza Impuls.

Klus-Stańska, D., Kalinowska A. (2004). Rozwijanie myślenia matematycznego młodszych uczniów. Warszawa: Wydawnictwo Akademickie Żak

Klus-Stańska, D., Nowicka, M., (2005). Sensy i bezsensy edukacji wczesnoszkolnej. Warszawa: WSiP.

Nowik, J. (2009). Kształcenie matematyczne w edukacji wczesnoszkolnej. Opole: Wydawnictwo Nowik.

Semadeni, Z. (1981). Nauczanie początkowe matematyki (Tom 1). Warszawa: WSiP.

Siwek, H. (2005). Dydaktyka matematyki. Warszawa: WSiP.

Swoboda E., Gunčaga J. (2009). Dziecko i matematyka. Rzeszów: Wydawnictwo Uniwersytetu Rzeszowskiego.

Węglińska, M. (1999). Motywacje szkolne dzieci w młodszym wieku. Szczecin: Wydawnictwo Naukowe Uniwersytetu Szczecińskiego.

Zborowski, J. (1986). Rozwijanie aktywności twórczej dzieci. Warszawa: WSiP.

Podstawa programowa kształcenia ogólnego dla szkół podstawowych 2008. Taken from: http://195.136.199.90/images/stories/pdf /Reforma/1c.pdf 